\title{
Skill Assessment of Sixth Semester Counseling Students in Cross-Cultural Counseling Practices
}

\author{
Evia Darmawani* \\ Guidance and Counseling Program \\ Palembang PGRI University \\ Palembang, Indonesia \\ evia.syamsuddin@gmail.com*
}

\author{
Muhammad Ferdiansyah \\ Guidance and Counseling Program \\ Palembang PGRI University \\ Palembang, Indonesia \\ mferdiansyah34@yahoo.com
}

\author{
Arizona \\ Guidance and Counseling Program \\ Palembang PGRI University \\ Palembang, Indonesia \\ arizona.karno@gmail.com
}

\author{
Nurlela \\ Guidance and Counseling Program \\ Palembang PGRI University \\ Palembang, Indonesia \\ nurlelampd97@gmail.com
}

\author{
Bela Janare Putra \\ Guidance and Counseling Program \\ Palembang PGRI University \\ Palembang, Indonesia \\ belajanare12@gmail.com
}

\begin{abstract}
This study aims to obtain assessment data from which data is used to improve the quality of cross-cultural guidance and counseling course. research using evaluation methods with a case study approach. Data were collected using interview, observation, documentation and focus group discussion Informants was obtained using purposive sampling techniques. This study revealed that: a) sixth semester counseling students experience errors in diagnosing problems in counseleefrom different cultural background b) students' has weakinsights regarding counselee's culture c) Weak ability to build therapeutic relationships, d) difficulties in empathy and e) erroneous exploration ofcounselee's problems. From these findings we recommend for the guidance and counseling study program Palembang PGRI University to conduct a curriculum review by adding the proportion of practical courses to the curriculum of the study program.
\end{abstract}

Keywords-assessment, guidance and counseling student skills, cross-cultural counseling

\section{INTRODUCTION}

Indonesia is a country with the fourth largest human population in the world. This contributes to the diversity and variation in Indonesia's cultural, political, and social portraits, Strong interaction between one culture with another culture within Indonesia has always been dynamic and has a long historical background. Indoensia treats its' cultural diversity as one of its' riches. However, it is undeniable that the potential for disunity due to cultural difference can also potentially lead to friction and discord, therefore counselors should be aware that such diversity will lead to variety in human dynamics conditions.

In cross-cultural counseling, the goals to be achieved must not be impeded by cultural differences between counselor and counselee. This obviously refers to the philosophical foundation which is often expressed as an inherent dignity in the individual, respect for individuality, individual rights for self-actualization and others, indicating the counselor's commitment to effective counseling for all counselees regardless of cultural, ethnic or religious background the economy. However, as important as that commitment is that counselors must move towards active pursuit of appropriate theoretical foundations, and effective practices, if they want to succeed in doing counseling with different cultural backgrounds [1].

Guidance and Counseling study program (hereinafter abbreviated as GC) of FKIP Palembang PGRI University as one of the institution that provides guidance and counseling education in South Sumatra, should play an active role in improving the quality of its graduates. Ferdiansyah and Efrianto points out that along with the development, GC students need to be equipped with a set of insights, knowledge, skills and attitudes to respond to the accelerating progress of the era [2]. To achieve this, Ferdiansyah emphasized that lecturers as one of the important components in an educational institution tasked with transforming knowledge in GC course, should be able to equip GC students with recent strategies or methods in the GC field. For this reason, the material to be taught, of course, must have clear standards and objectives for achievement. In order to produce quality graduates.

Referring to the explanation, it is realized that $\mathrm{BK}$ of FKIP University of Palembang PGRI study program is still not maximized in producing graduates who can help administer BK professionally in schools, especially in South Sumatra. This is reinforced by research conducted by Ferdiansyah \& Efrianto in 2018, found that the pattern of BK teachers in (alumni of the University of PGRI Palembang) in handling students with problems is still dominant using the disciplinary approach [3]. Based on the research findings, of course various improvement efforts are being pursued by the BK study program in maximizing the quality of students and graduates so that they can contribute greatly in improving the quality of counseling services in schools. 
GC students as prospective counseling professionals should understandthat the language and dialect differences between counselor and their counselee have a major influence on the success of counseling, therefore counselor shoul understand the difference and discrepancies between their culture and the culture of their counselee that might affect the counseling process.

Furthermore, in order to become a culturally competent counselor, students must first ask themselves, "what is my understanding of cross-cultural counseling?" There are many cultural aspects that may have impact on counseling, such as language, habits, values, beliefs, spirituality, gender roles, socio-political history, etc. Dyche and Zayas in 1995 demonstrates that most multicultural counseling practices are driven by a set of principles or beliefs, not based on a set of techniques or special skills [3]. Multicultural counselors can use various forms of delivery, ranging from individuals, couples, families or groups, and take advantage of certain interventions such as relaxation training, dream analysis, or empathic reflection.

In the context of South Sumatra, ability to conduct multicultural counseling is a valuable asset as South Sumatra is a province with diverse demographic conditions. In terms of ethnicity, South Sumatra Province has diverse ethnic groups such as Gumai, Ogan, Lematang, Palembang, Komering and others, each of which has different characteristics from language, customs, beliefs and daily habits. Therefore, in doing counseling, counselors should have broad cultural insights, in order to be able to use various emic and ethical approaches in the counseling process.

Furthermore, cross-cultural counselor competencies must focus on the important skills possessed by counselors including: (1) Appropriate attitudes and beliefs in the sense that they are aware of assumptions, values and biases, (2) Knowledge needed about their client's culture so that they can better understand their clients, (3) repertoire of skills or tools that can be effectively applied to clients from various backgrounds [4]. Therefore, we as the researcher, recognizes the importance of cross-cultural counseling skills in the success of the counseling process especially in the context of South Sumatra. Thus, evaluation of cross-cultural counseling course needs to be done within the guidance and counseling study program FKIP Palembang PGRI University.

\section{METHODS}

This study uses a qualitative evaluation research design with a case study model. According to Yusuf evaluation research aims to assess ongoing process [5], in this case the researcher will evaluate the learning process of crosscultural counseling implementation skills that are taught in the sixth semester, to obtain the correct data we employ purposive sampling techniques in determining informants for this study. The findings of the next study were tested for validity through four criteria, namely (1) the Trust test (2) Transparency test, (3) Defendability test (4) Conformity test [6]. Furthermore, Yin Roberts that the findings in the field can be arranged systematically, then dominant analysis was applied to interpret the data dominant analysis consists of three sub-activities namely pattern matching, explanation, time series analysis [7].

\section{RESULT AND DISCUSSION}

Based on data and facts while in the field, various phenomena were found to be expected to be material for improvement for the BK Study Program in the Faculty of Teacher Training and Education, PGRI University Palembang in an effort to improve lecture patterns. In order to be understood the following researchers explain based on the focus and purpose of the study. After the researchers conducted data collection activities through interviews, observations, documentation studies.

Based on observations of interviews and documentation studies, data are obtained that in the practice of implementing cross-cultural counseling students experience quite a variety of obstacles, as stated by "MD" as follows:

"I do not yet have sensitive feelings about what is desired by the counselee, especially for counseling with a different perspective in seeing things with me, for example when I do counseling with people who have strong beliefs about things that are magical that tend to lead to irrational things. I have difficulty doing counseling with a cultural approach." (Interview, Tuesday 3 February 2019)

From the explanation above, the researcher gets information that when counseling with counselees who have different cultural views, students tend to erroneously diagnose problems and interpret what is the counselee's problem. Not only that, researchers also obtained data through observations when sixth semester students practiced cross-cultural counseling, students were not yet skilled in exploring the problems experienced by clients, lacked skills in making open questions and tended to get stuck in stereotypical perceptions about counselees causing the implementation of counseling to appear undeveloped.

What was experienced by the sixth semester students was similar to Scheutz as cited Lago showing that "all coherent cultural knowledge and practices are only partially clear and are not free from contradictions (resistance / differences) [2]. This statement has 2 implications namely (1) when we look at the culture of others we have (maybe inconvenience) experience in understanding phenomena that are not all directly clear. (2) when we examine ourselves, we cannot appreciate the incoherence and contradiction that exists unless we are assisted by outsiders. Therefore, efforts need to be made in the multicultural counseling movement to find ways to facilitate the development of awareness, knowledge, and appropriate cultural skills.

For this reason, a student as an effective cross-cultural counselor candidate should have an awareness of his own cultural background and have actively gained further awareness about his own biases, stereotypes, and values. Although an effective cross-cultural counselor cannot hold the same belief system as his client, he can accept the different world views presented by a helper. In other words, "Differences are not seen as deviations". Being sensitive to 
differences and broadcasting one's own cultural bias allows effective cross-cultural counselors to refer counselees from non-dominant groups to the counselor's own cultural counselor when referrals will benefit the helper. Unfortunately, the examples of mental health professionals who have failed are culturally different from themselves as a result of their own general biases and prejudices.

Students as prospective cross-cultural counselors should ideally be able to apply, adapt, generic interview and counseling skills and also have knowledge and have special skills and interventions that may be effective with clients from diverse cultural groups. BK students should also have knowledge and understand the client's verbal and nonverbal language and be able to communicate effectively.

In addition, a BK student is ideally skilled to appreciate the importance of having a systemic perspective, regarding understanding of the impact of family and community on counselees, being able to work with community leaders, colleagues, and other professionals. What happens when BK students do not have the right skills when working with students of diverse cultures? Most likely, students who will become counselees will feel hopeless and dissatisfied with counseling services.

\section{CONCLUSION}

Cross-cultural counseling involves counselors and counselees that involve different cultural backgrounds, therefore the counseling process is prone to cultural bias from the counselor that can hinder the counseling process. The need for BK students as prospective counselors to have cultural sensitivity to be able to understand and help counselees, this is so that BK students as prospective counselors appreciate the individual dimension inherent in the individual counselee. Knowledge, attitudes and intervention skill in cross-cultural counseling relationships will determine the success of the cross-cultural counseling process. Based on the research findings, the researcher suggests that the study program implementers/personnel have a strong commitment in conducting the lecture process, especially in the practice of expertise courses, so that the organization of education is now improved again in order to produce quality students and graduates and contribute greatly to the delivery of services school counseling.

\section{REFERENCES}

[1] Iswari Mega, 2013. Efefective of Counseling Process With Understanding Communication Bettwen Culture. Prosiding Seminar Internasional Konseling. Bali: Undiksha

[2] Ferdiansyah, M \& Efrianto. (2018). Pola Guru Bimbingan dan Konseling dalam Penanganan Siswa Bermasalah di SMA PGRI 4 Palembang.Journal of Innovative Counseling : Theory,Practice \& Research, 1 (1): pp. 91-94

[3] Neukrug Edward S., 2012. Theory, Practice, and Trends in Human Services .USA: Cangage-Global

[4] Ferdiansyah, M. (2015). Dasar Penelitian Kualitatif. Bogor : CV. Herya Media

[5] Yusuf. A. Muri (2013). Metode Penelitian; Kuantitatif, Kualitatif dan Penelitian Gabungan. Padang: UNP Preess

[6] Yin. Robert. K (2018). Studi Kasus. Desain dan Metode. Terjemahan oleh M. Zauzi Muzakir. Jakarta: PT Raja Grafindo

[7] Lago. Collin ( 2006 ). Race, Culture and Counselling The Ongoing Challenge. England: McGraw-Hill House 